УДК 004.05

[0000-0003-2007-9943] I. В. Миронець, к.т.н., доиент,

e-mail: irenmir30@gmail.com

А. В. Бобошко, магістрант

e-mail: boboshkoa@meta.ua

Черкаський державний технологічний університет

б-р Шевченка, 460, м. Черкаси, 18006, Україна

\title{
УДОСКОНАЛЕННЯ ІНФОРМАЦІЙНОЇ СИСТЕМИ МОНІТОРИНГУ ОСВІТНЬОГО ПРОЦЕСУ
}

Досліджено актуальні аспекти застосування інформаційних систем в освітньому процеci. Розроблено й удосконалено інформаційну систему для іOS-пристроїв, яку було створено на базі закладу вищзӧ освіти (3ВО), щзо дає змогу за рахунок оперативного доступу й аналітичного опрацювання статистичних даних підвищити результативність освітнього процесу. 3 а результатами удосконалення програмного забезпечення для обробки статистичних даних $i$ проведення експерименту надано обгрунтування щуодо доцільності впровадження таких систем в освітній процес. Доведено, щзо удосконалення інформаційної системи моніторингу освітнього прочесу впливає на успіхи в навчанні за рахунок економї часу, а в изілому інформаційні системи в освіті дають змогу оптимізувати використання інформачійно-ресурсної бази ЗВО, підвищити комфортність навчання для здобувачів освітніх послуг і конкурентоспроможність освітнього закладу.

Ключові слова: інформаційна система, статистичні дані, освітній процес, удосконалення, дослідження, експеримент, програмне забезпечення.

Вступ. Швидкі темпи інформатизації суспільства привели до значних змін у повсякденному житті і професійній діяльності. Інформатизація освіти $є$ ключовою умовою підготовки фахівців, здатних працювати у кардинально нових, дедалі більш автоматизованих, умовах праці. Сучасна людина в умовах інформаційного суспільства прагне досягти максимального комфорту при навчанні й трудовій діяльності, чому сприяє користування мережею Інтернет.

На рисунку 1 продемонстровано найбільш відвідувані Інтернет-джерела в Україні станом на липень 2019 р. [1].

Інформаційні ресурси стали доступнішими через те, що в сучасному суспільстві в будь-який час завжди є можливість підключитися до мережі за допомогою різноманітних мобільних додатків, які встановлені на смартфон або планшет.

На рисунку 2 продемонстровано статистику користувачів Інтернету, мобільних пристроїв та найрізноманітніших мобільних систем, які широко використовуються в різних сферах. Нині постійно створюються нові, сучасніші й досконаліші засоби з використанням сучасних технологій, що впливає на швидкодію і функціональність відповідних систем.

Фахівцями розроблено безліч новинок у сфері мобільних додатків, які дають змогу вирішувати завдання, що в результаті дає можливість швидко реагувати на поставлену задачу, економити час i досягати максимально комфортного рівня життя.

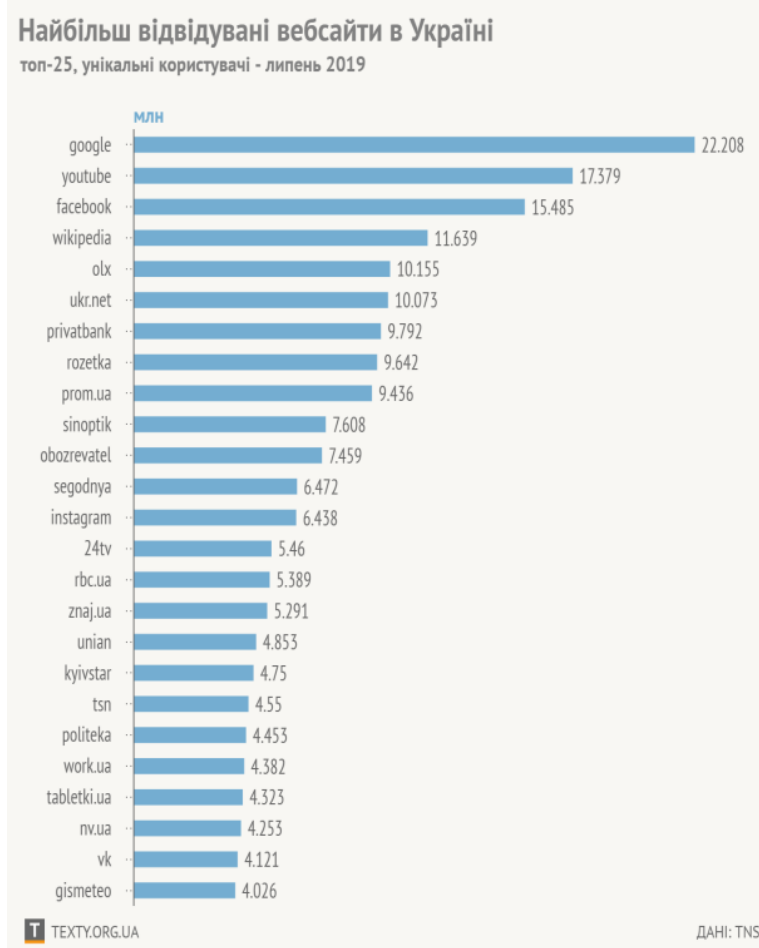

Рисунок 1 - Найбільш відвідувані веб-сайти в Україні за 2019 рік [2] 
Разом 3 тим, збільшується кількість інформації, і її стало надзвичайно багато. Передбачається, що до 2020 р. на планеті буде 50 млрд. підключених пристроїв, 3 них 6,1 млрд. - смартфони. Населення Землі досягне 7,75 млрд. (тобто в 6,5 разу менше підключених пристроїв), і кожний житель буде генерувати 1,7 Мб інформації в секунду. Приблизно третина всіх даних буде зберігатися в «хмарному» сховищі [1].

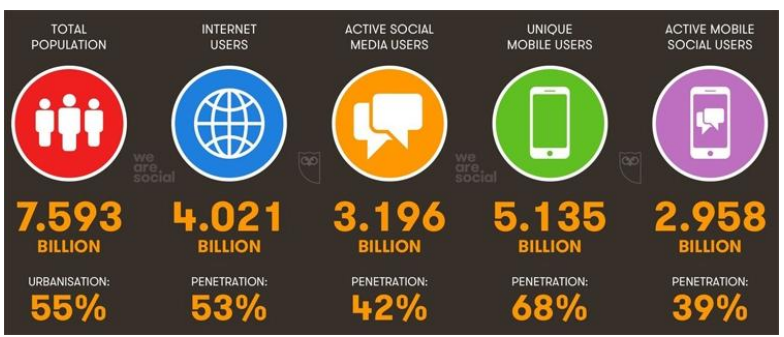

Рисунок 2 - Загальна відсоткова статистика користувачів у світі за 2019 рік [3]

У 2018 р. загальний обсяг даних в Інтернеті становив близько 22 Збайт, кожні два роки це число подвоюється. Ймовірно, до 2020 р. цей показник зросте до 44 Збайт [1].

Для того, щоб розмістити всю цю інформацію на накопичувачах, потрібно буде приблизно 4,4 млрд. 10-терабайтних накопичувачів. Якби кожний терабайт у зетабайті був кілометром, то це було б еквівалентно 1300 поїздкам на Місяць і назад (76 800 км). Якби кожний гігабайт у зетабайті був метром, то він би охопив протяжність річки Амазонки (найдовшої річки в світі - 6992 км) більш ніж у 150000 разів. Якби кожний гігабайт у зетабайті був цеглиною, можна було б побудувати 258 великих стін Китаю (з 3873000000 цеглин). 3 цих прикладів можна зрозуміти, що інформації стало набагато більше, і іiі кількість не перестає збільшуватись.

Беручи до уваги рисунок 3 , можна дійти висновку, що інформаційними технологіями здебільшого користуються студенти. 3 цього випливає, що молодь найкраще розуміє проблему пошуку інформації: адже для того щоб стати фахівцями своєї галузі, просто необхідно володіти великою кількістю інформації.

Студенти, які активно користуються сучасними гаджетами, отримують інформацію переважно за їх допомогою. Таким чином, можна стверджувати, що основною причиною оптимізації та удосконалення програмного забезпечення для цього кола користувачів $\epsilon$ розвиток технологій для кишенькових гаджетів і збільшення кількості інформації, яку су-

(C) I. В. Миронець, А. В. Бобошко, 2019 DOI: $10.24025 / 2306-4412.4 .2019 .182838$ часний здобувач освіти повинен освоювати в процесі свого навчання.

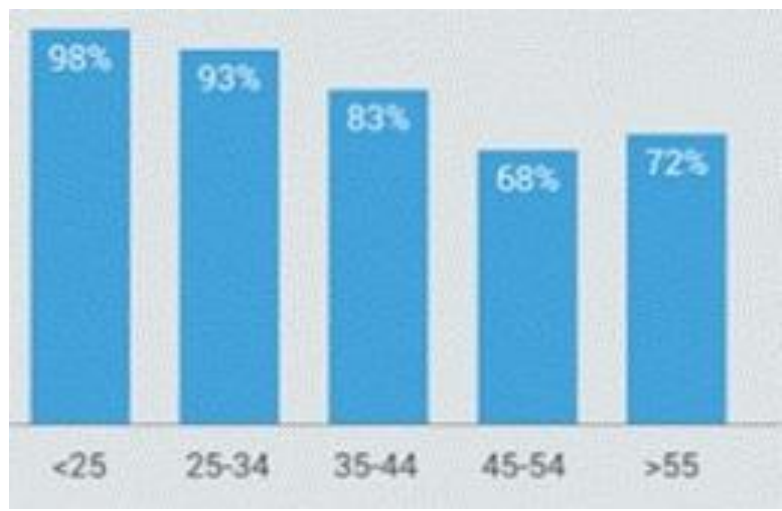

Рисунок 3 - Статистика використання мережі Інтернет за допомогою мобільних пристроїв серед різних вікових категорій за 2019 рік [4]

Провівши аналіз досліджень щодо застосування інформаційних технологій в освіті $[5,6,7]$, було визначено, що це питання є досить актуальним для майбутніх спеціалістів будь-яких професій. Інформаційні системи мають значний вплив на розвиток студентів та їх становлення як майбутніх фахівців [5].

Дослідження такого впливу є дуже важливим, але в реаліях сучасності не всі заклади освіти приділяють цьому питанню достатню увагу, тому це $\epsilon$ важливою проблемою. Однією 3 найважливіших складових вирішення цієї проблеми $є$ доведення та обгрунтування того факту, що сучасні інформаційні технології необхідно інтенсивніше впроваджувати в освітній процес - як $з$ огляду на підвищення вимог до якості освіти, так і зважаючи на необхідність моніторингу освітнього процесу в освітніх закладах $[6,7,14]$, який проводиться 3 урахуванням вимог Закону України «Про освіту», Закону України «Про вищу освіту», стандартів і рекомендацій щодо забезпечення якості в Свропейському просторі вищої освіти ESG 2015 р. та нормативних документів закладів освіти. Моніторинг стейкхолдерів щодо якості освіти і освітньої діяльності є складовою системи внутрішнього забезпечення якості освіти і освітньої діяльності у закладі вищої освіти [14]. Метою такого моніторингу $\epsilon$ отримання об'єктивної інформації щодо очікувань та задоволення здобувачами вищої освіти, випускниками, роботодавцями та іншими зацікавленими особами якістю освіти i станом освітнього процесу, забезпечення зворотного зв'язку між усіма учасниками освітнього процесу, розробка пропозицій щодо його удосконалення. 
Метою дослідження $є$ вдосконалення наявної інформаційної системи моніторингу освітнього процесу для iOS-пристроїв, що дозволить підвищити ефективність ії використання в закладах вищої освіти.

Для досягнення мети було сформульовано та вирішено наступні завдання:

1) на основі дослідження проблеми інформатизації в закладах освіти зробити обгрунтування необхідності удосконалення інформаційної системи моніторингу освітнього процесу;

2) розглянути загальні методики та методи досліджень щодо отримання інформації;

3) оцінити ефективність роботи вдосконаленої інформаційної системи та проаналізувати отримані результати.

Опис об'єкта та методу дослідження. Об'єктом дослідження у статті є інформаційна система моніторингу освітнього процесу у вигляді мобільного додатка. Розроблялася ця інформаційна система для закладу вищої освіти з метою покращення ефективності і якості освітнього процесу (рисунок 4).

В будь-якому закладі вищої освіти (3ВО) використовується велика кількість інформації, яка розрахована на студентів і викладачів, але користуватися цією інформацією незручно, тому що вона знаходиться на різних джерелах або ж отримати іiі може студент особисто на кафедрі чи в деканаті (наприклад, щодо власних результатів навчання, перспектив і наукових досліджень або проблем, що виникають).

Спираючись на зазначене вище та враховуючи проблеми інформатизації в закладах освіти, виникла ідея створення модернізованого мобільного додатка для допомоги студентам - $з$ огляду на необхідність впровадження і вдосконалення подібних систем у закладах вищої освіти (рисунок 5). 3 одного боку, заклад освіти отримає інструментарій для оперативного i повного інформування здобувачів освітніх послуг та для моніторингу освітнього процесу. 3 другого боку, студентам не потрібно буде витрачати час на пошук інформації стосовно освітнього процесу в навчальному закладі, а можна буде спрямувати цей час на отримання знань. Студентство - це майбутнє кожної держави, отже, важливо надати їм якомога більше простору для розвитку в межах закладу освіти, підвищуючи тим самим його конкурентоспроможність.

За основу було взято наступні методи дослідження:
1. Опитування як один із найпоширеніших методів для отримання інформації. Цей метод важливий у дослідженні, оскільки це один із найпоширеніших методів для отримання інформації. До опитування вдаються, коли єдиним джерелом інформації є людина - безпосередній учасник, представник, носій досліджуваних явищ чи процесу.

За допомогою опитування можна одержати інформацію, не завжди відображену в документальних джерелах чи доступну прямому спостереженню [8]. Види опитувань: письмове - анкетування; усне - інтерв'ю, бесіда.

3 метою підвищення якості освіти й освітньої діяльності та врахування результатів опитування в управлінській діяльності основними видами опитування, що застосовуються в університеті, $є$ анкетування та інтерв'ю. Анкетування - метод опитування, при якому респондент самостійно заповнює анкету. Передбачається можливість проведення групового або індивідуального анкетування. Анкета, за винятком випадків, коли $є$ потреба 3'ясувати особисту думку конкретного респондента, $є$ анонімною. Анкети заповнюються респондентами самостійно. У випадку, коли анкетування потребує зазначення даних про респондента (прізвища, імені, курсу і номеру академічної групи тощо) обов'язковою є умова його особистої згоди [14].

2. Спостереження як метод наукового дослідження полягає в активному (систематичному, цілеспрямованому, планомірному) та навмисному сприйнятті об'єкта, в ході якого здобуваються знання про зовнішні сторони, властивості й відносини досліджуваного об'єкта 3 метою майбутнього використання для практичної діяльності. Спостереження включає такі елементи: спостерігача, об'єкт спостереження та засоби спостереження [9].

3. Експеримент - один із основних методів наукового дослідження, в якому вивчення явищ відбувається в доцільно вибраних або штучно створених умовах, які забезпечують появу тих процесів, спостереження яких необхідне для встановлення закономірних зв'язків між явищами [10]. Експеримент проведеного дослідження полягав у тому, щоб надати тестовій групі доступ до відкоригованої версії системи та провести аналіз впливу використання системи на успішність користувачів у навчанні, а саме: без використання та 3 використанням вже розробленої, удосконаленої системи за допомогою попередніх методів дослідження. 


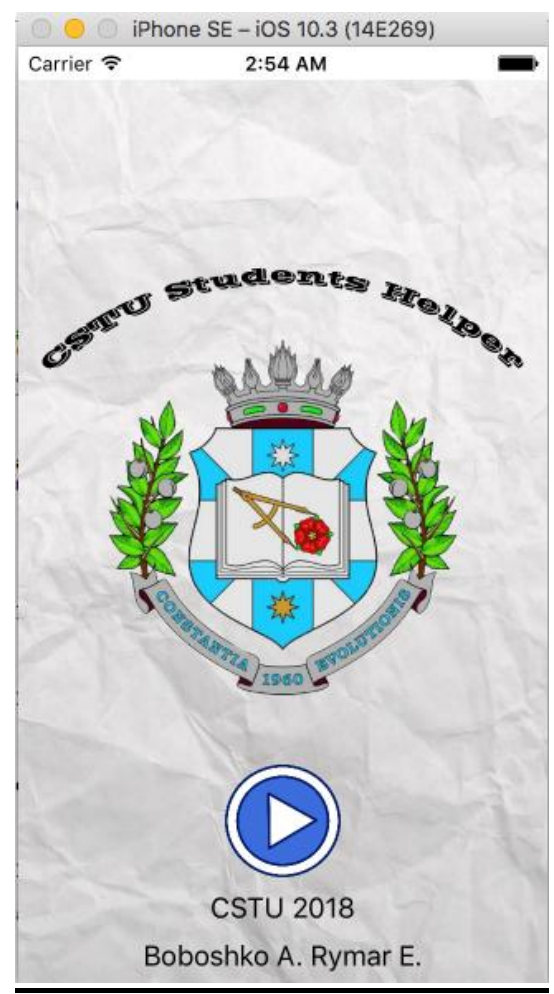

Рисунок 4 - Інформаційна система для закладу вищої освіти. Стартове вікно
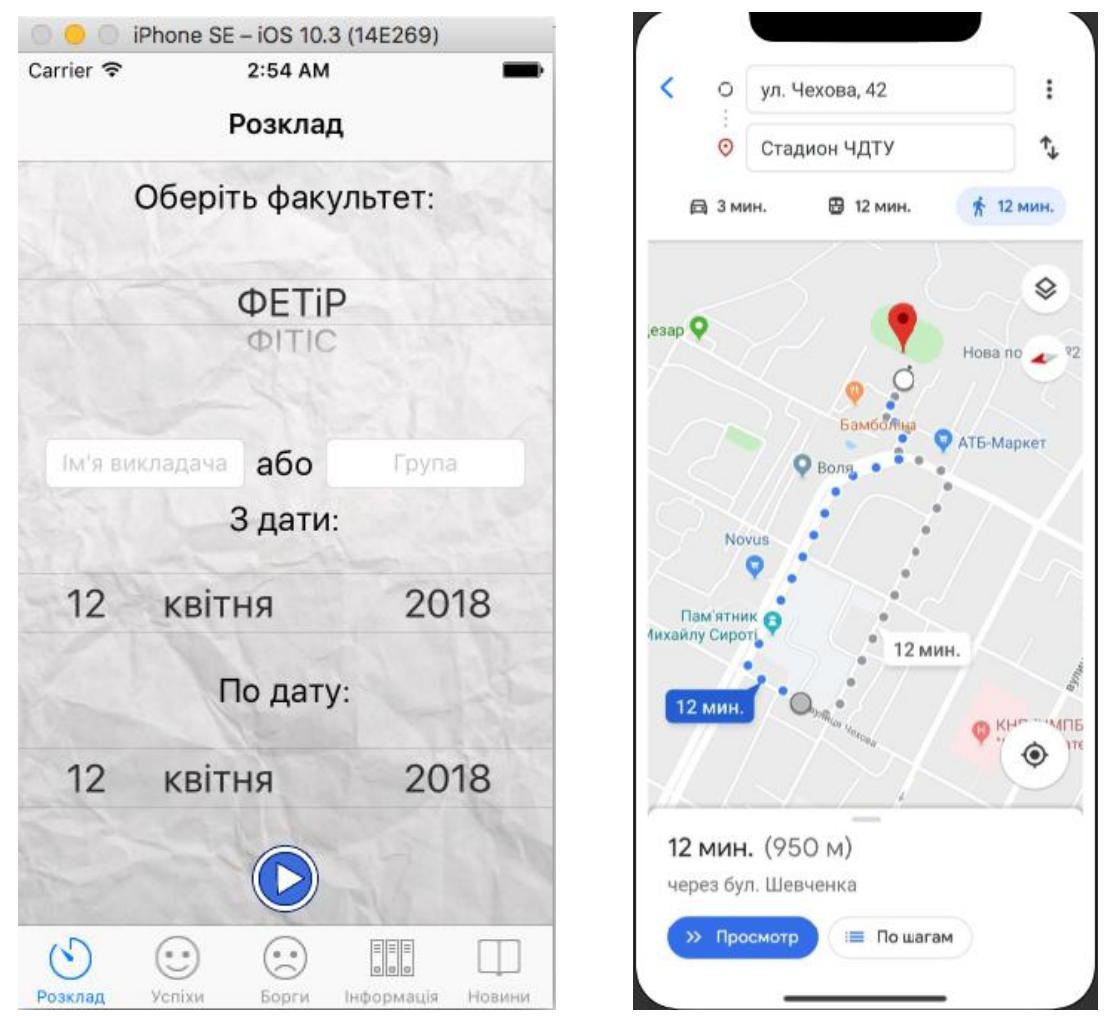

а) вікно для пошуку розкладу;

б) вікно для пошуку маршруту

Рисунок 5 - Інформаційна система після вдосконалення 
Опис результатів. Опис того, як саме проводилися зазначені дослідження, та інтерпретацію одержаних результатів наведено нижче в тому порядку, в якому вони були здобуті при проведенні дослідження.

1. Опитування проводилося у вигляді анонімного анкетування, в якому з 50 осіб, що проходили опитування, 43 - обрали варіант за впровадження подібних систем в освітній процес, 7 - обрали варіант, який пропонував залишити все так, як є на сьогоднішній день. 43 особи, які обрали варіант впровадження подібних систем, запропонували внести в наданий їм тестовий зразок такі доповнення та коригування:

- додати підтримку операційної системи Android;

- додати більше безпеки для захисту інформації користувача;

- додати можливість прокласти маршрут до обраної аудиторії або іншого місця призначення, пов'язаного 3 освітнім процесом;

- додати сповіщення (попередження про зміни в розкладі);

- off-line режим;

- змінити користувацький інтерфейс для зручності.

Перед впровадженням цих змін в існуючу систему було проведено дослідження, чи дійсно нові функції збігаються 3 потребами користувачів, чи варто було б додати інші функції. Приділялося багато часу питанню, наскільки просто та інтуїтивно зрозуміло користуватися цією системою. Варто зазначити, що багато уваги було приділено зовнішньому вигляду системи. Адже, якщо порівнювати дві системи з однаковими функціями, але в одній більше приділено уваги зовнішньому вигляду, а в другій - зовсім мало, то користувач буде продуктивнішим у тій системі, яка «приємно» виглядає [11].

Продуктивність досягається навіть за рахунок правильно підібраних кольорів, які не будуть втомлювати та відволікати користувача від продуктивного сеансу в системі.

2. Спостереження. Додавши запропоновані удосконалення, нову версію системи було запропоновано до користування, через деякий час було переглянуто аналітику та крашалітику відредагованої системи.

Під час аналізу відповідних даних було знайдено кілька некритичних помилок, які швидко були усунуті. Розпочалася фаза підготовки системи до майбутнього експерименту, під час якої було обрано кандидатів для так званого «АБ тестування».

3. Експеримент. «АБ тестування» метод дослідження, суть якого полягає в тому, що контрольна група порівнює один або декілька показників, для того щоб з'ясувати, які зі змін покращують цільовий показник, та як саме покращують $[12,13]$.

Підготувавши все для тестування та заповнивши систему тестовими даними, iї було передано тестовій групі. Мета експерименту полягала в тому, що одна група буде робити все, як зазвичай, для пошуку інформації стосовно освітнього процесу, а другій групі наданий тестовий примірник системи, який дасть змогу зменшити витрачений час на пошук тієї ж інформації.

Результат зібраних даних наведено нижче, де у вигляді таблиці висвітлено, наскільки змінюється витрачений час на виконання монотонних дій щодня при звичному для всіх освітньому процесі і після впровадження сучасних інформаційних систем та пристроїв у цей процес (таблиця 1).

Таблиця 1 - Результати «АБ тестування»

\begin{tabular}{|l|c|c|}
\hline \multicolumn{1}{|c|}{ Вид діяльності } & $\begin{array}{c}\text { Витрачений час на виконання } \\
\text { операції групою A } \\
\text { (без використання системи) }\end{array}$ & $\begin{array}{c}\text { Витрачений час на вико- } \\
\text { нання операції групою } 5 \\
\text { (з використаннял системи) }\end{array}$ \\
\hline $\begin{array}{l}\text { Пошук інформації стосовно } \\
\text { успішності в навчанні }\end{array}$ & $\begin{array}{c}30 \text { хв., за умови близького роз- } \\
\text { ташування з університетом }\end{array}$ & 5 хв. \\
\hline Пошук розкладу & 10 хв. & 2 хв. \\
\hline 3'ясування змін у розкладі & 15 хв. & $\begin{array}{c}1 \text { хв., за умови миттєвого } \\
\text { реагування на сповіщення }\end{array}$ \\
\hline $\begin{array}{l}\text { Створення маршруту до місця } \\
\text { призначення }\end{array}$ & 15 хв. & 2 хв. \\
\hline Всього: & $\sim 1$ год. 10 хв. & $\sim 10$ хв. \\
\hline
\end{tabular}


Висновки. Інформаційні системи широко використовуються в освіті і мають значний вплив на розвиток студентів і становлення їх як фахівців. Дослідження такого впливу $€$ дуже важливим і необхідним 3 огляду на підвищення якості освіти, управління успішністю та постійний моніторинг освітнього процесу, а також реалізацію принципу зворотного зв'язку здобувачів освітніх послуг і закладу освіти та ін. Але в реаліях сучасності не всі навчальні заклади приділяють цьому питанню достатню увагу. Проведене дослідження мало за мету вдосконалення наявної системи моніторингу освітнього процесу для iOSпристроїв, яку було створено на базі закладу вищої освіти. Об'єктом дослідження стала інформаційна система моніторингу освітнього процесу у вигляді мобільного додатка.

Було використано такі методи дослідження: опитування, спостереження і експеримент. Було використано письмове (анкетування) та усне (інтерв'ю) опитування. Після отримання результатів опитування було запропоновано внести певні корективи щодо покращення системи. Однак перед впровадженням цих змін в існуючу систему було проведено дослідження, чи дійсно нові функції збігаються $з$ потребами користувачів, чи варто було б додати інші функції.

Метод спостереження надав інформацію, необхідну для остаточного коригування системи (перевірка системи на наявність помилок та коректність іiі роботи) та налаштування перед експериментом. Додавши запропоновані удосконалення, нову версію системи було запропоновано до користування, через деякий час було переглянуто аналітику та крашалітику цієї системи.

Метод експерименту полягав у тому, щоб надати тестовій групі доступ до відкоригованої версії системи та провести аналіз впливу використання системи на успішність користувачів у навчанні, а саме: без використання та з використанням вже розробленої, удосконаленої системи за допомогою попередніх методів дослідження. Як результат - маємо порівняльну таблицю 3 висновками щодо досліджуваної системи.

Проведення дослідження можна вважати успішним, тому що різниця у витраченому часі на виконання рутинних і звичних користувачеві речей в середньому змінилася 3 1 години 10 хвилин на 10 хвилин (7\% від того часу, який витрачався раніше).

(C) I. В. Миронець, А. В. Бобошко, 2019 DOI: $10.24025 / 2306-4412.4 .2019 .182838$
Спираючись на результати дослідження, можна констатувати, що впровадження інформаційних систем подібного типу в освітній процес $є$ доцільним для ЗВО та інших освітніх закладів (з певними індивідуальними коригуваннями в самій системі).

Впровадження значно покращить навчальний процес для користувачів, вирішуючи одну з актуальних проблем інформатизації, заощаджуючи час для саморозвитку, самопідготовки i, власне, самого освітнього процесу, що має позитивно вплинути на успішність у навчанні, а також на участь у науковій та виховній складових. Впровадження піде на користь не лише студентам, а й самому ЗВО, адже і в абітурієнтів, і у студентів зросте рівень комфорту і довіри, а також розуміння того, що в закладі освіти піклуються про них. За рахунок цього має суттєво зрости і рейтинг самого ЗВО.

У процесі вирішення поставлених завдань у роботі одержано наступні результати:

1) на основі дослідження проблеми інформатизації в закладах освіти обгрунтовано необхідність удосконалення розробленої інформаційної системи моніторингу освітнього процесу;

2) розглянуто загальні методики, методи досліджень і обгрунтовано їх вибір та використання;

3) реалізовано оптимізацію мобільного додатка, проведено експеримент, виконано оцінку ефективності роботи системи та проаналізовано отримані результати.

Отже, запропоноване вдосконалення інформаційної системи моніторингу освітнього процесу дасть змогу, окрім економії часу, досягти максимального інформаційного комфорту для студентів у сучасних умовах та поліпшити конкурентоспроможність закладу освіти.

\section{Список літератури}

[1] Т. М. Корпанюк, та Я. І. Мулик, "Застосування мобільних", Ефективна економіка: електрон. фахове вид., № 1 (3), 2018.

[2] Режим доступу: http://texty.org.ua/pg/ news/textynewseditor/read/95692/google_y outube_facebook_ale_j_novynni?a_offset

[3] Режим доступу: https://wearesocial.com/ blog/2018/01/global-digital-report-2018 
[4] Режим доступу: https://tehnot.com/ua/ google-vyyasnil-skolko-ukraintsevpolzuetsya-smartfonami/

[5] І. Ю. Хомишин, "Сучасні інформаційні технології в освіті", IT право: Проблеми $i$ перспективи розвитку в Україні, $\mathrm{APhD}$, 2019. [Електронний ресурс]. Режим доступу: http://aphd.ua/publication-157/

[6] О. В. Андрощук, Ю. В. Кондратенко, О.В. Головченко, Т. О. Ворона, та М. В. Петрушен, "Інформаційні технології та їх вплив на розвиток суспільства", Збірник наукових пращь Центру воєнностратегічних досліджень Національного університету оборони України імені Івана Черняховського, № 1 (50), 2014.

[7] О. Л. Перевозчикова, Информачионные системы и структуры данных: учеб. пособие для студентов вузов / Нац. ун-т "Киево-Могилянская академия". Москва, Россия: КМ Академия, 2007.

[8] В. I. Зацерковний, I. В. Тішаєв, та В. К. Демидов, Методологія наукових досліджень: навч. посіб. Ніжин, Україна, 2012.

[9] О. О. Железняк, та I. В. Корнієнко, Наука та наукові дослідження: навч. посіб. Ніжин, Україна, 2007.

[10] О. В. Колєсніков, Основи наукових досліджень: навч. посіб., 2-ге вид., випр. та доп. Київ, Україна, 2011.

[11] Jaime Levy, UX strategy: how to device innovative digital products that people want. O'Reilly Media, 2015.

[12] Charles Wheelan, Naked statistics. WW Norton \& Company, 2014.

[13] Е. В. Чекотовський, Статистичні мето$\partial u$ : навч. посіб. Київ, Україна: Знання, 2016.

[14] Положення про моніторинг стейкхолдерів щодо якості освіти і освітньої діяльності Черкаського державного технологічного університету. Черкаси, 2019. [Електронний ресурс]. Режим доступу: http://chdtu.edu.ua

\section{References}

[1] T. M. Korpaniuk, and Ya. I. Mulik, "Mobile application", Efektyvna ekonomika: electron. prof. ed., no. 1 (3), 2018 [in Ukrainian].
[2] Режим доступу: http://texty.org.ua/pg/ news/textynewseditor/read/95692/google_y outube_facebook_ale_j_novynni?a_offset

[3] Режим доступу: https://wearesocial.com/ blog/2018/01/global-digital-report-2018

[4] Режим доступу: https://tehnot.com/ua/ google-vyyasnil-skolko-ukraintsevpolzuetsya-smartfonami/

[5] I. Yu. Khomyshyn, "Modern information technologies in education", IT pravo: Problemy $i$ perspektyvy rozvytku $v$ Ukraini, APhD, 2019. [Online] Available: http://aphd.ua/publication-157/

[6] O. V. Androschuk, Yu. V. Kondratenko, O. V. Golovchenko, T. O. Vorona, and M. V. Petrushen, "Information technologies and their influence on society development", Zbirnyk naukovykh prats Tsentru voiennostratehichnykh doslidzhen Natsionalnoho universytetu oborony Ukrainy imeni Ivana Cherniakhovskoho, no. 1 (50), 2014 [in Ukrainian].

[7] O. L. Perevozchikova, Information systems and data structures: textbook for university students; National University "Kyiv-Mohyla Academy". Moscow, Russia: KM Akcademy, 2007 [in Russian].

[8] V. I. Zatserkovny, I. V. Tishaev, and V. K. Demidov, Methodology of scientific research: textbook. Nizhyn, Ukraine, 2012 [in Ukrainian].

[9] O. O. Zheleznyak, and I. V. Kornienko, Science and scientific research: textbook. Nizhin, Ukraine, 2007 [in Ukrainian].

[10] O. V. Kolesnikov, Fundamentals of scientific research: textbook, the 2 nd ed., cor. and suppl., Kyiv, Ukraine, 2011 [in Ukrainian].

[11] Jaime Levy, UX strategy: how to device innovative digital products that people want. O'Reilly Media, 2015.

[12] Charles Wheelan, Naked statistics. WW Norton \& Company, 2014.

[13] E. V. Chekotovsky, Statistical methods: textbook. Kyiv, Ukraine: Znannya, 2016 [in Ukrainian].

[14] Regulations on stakeholder monitoring of the quality of education and educational activities of Cherkasy State Technological University. Cherkasy, 2019. [Online] Available: http://chdtu.edu.ua 
I. V. Myronets, $P h$. D., associate professor, e-mail: irenmir30@gmail.com

A. V. Boboshko, master, e-mail: boboshkoa@meta.ua

Cherkasy State Technological University

Shevchenko blvd, 460, Cherkasy, 18006, Ukraine

\section{IMPROVEMENT OF THE INFORMATION SYSTEM FOR EDUCATIONAL PROCESS MONITORING}

The article investigates the essence of information systems and the results of their use in educational process. The rapid pace of society informatization has led to significant changes in daily life and professional activities. Informatization of education is a key prerequisite for training professionals able to work in radically new, increasingly automated, working conditions. The purpose of the study is to improve the existing information system for educational process monitoring for iOS devices which will increase its efficiency in higher education institutionss. The article describes the object and methods of the study, considers their features and the process of the experiment. Conducting the survey can be considered successful because the difference in the time spent on performing of such simple and familiar things to the user on average has changed from 1 hour 10 minutes to 10 minutes ( $7 \%$ of the time previously spent).

Based on the results of the study, it can be stated that the implementation of information systems of this type in educational process is appropriate for higher educational institutions and other educational institutions (with certain individual adjustments in the system itself). The implementation will significantly improve the learning process for users by addressing one of the pressing problems of informatization, saving time for self-development, or better training for the educational process itself, which should have a positive impact on the success in learning. The implementation will benefit not only students but also the institution of higher education itself, because both students and university entrants will increase the level of trust and understanding, that they are cared for. Due to this, the rating of higher educational institution has to increase significantly In the process of solving the set tasks in the work the following results have been obtained: 1) the feasibility of improving the developed information system is substantiated on the basis of research;2) general and research methods are considered and their selection and use are substantiated; 3) optimization of the mobile application is carried out, the experiment is conducted and the obtained results are analyzed.

Keywords: information system, statistical data, educational process, improvement, research, experiment, software.

Стаття надійшла 15.11.2019

Прийнято 02.12.2019 